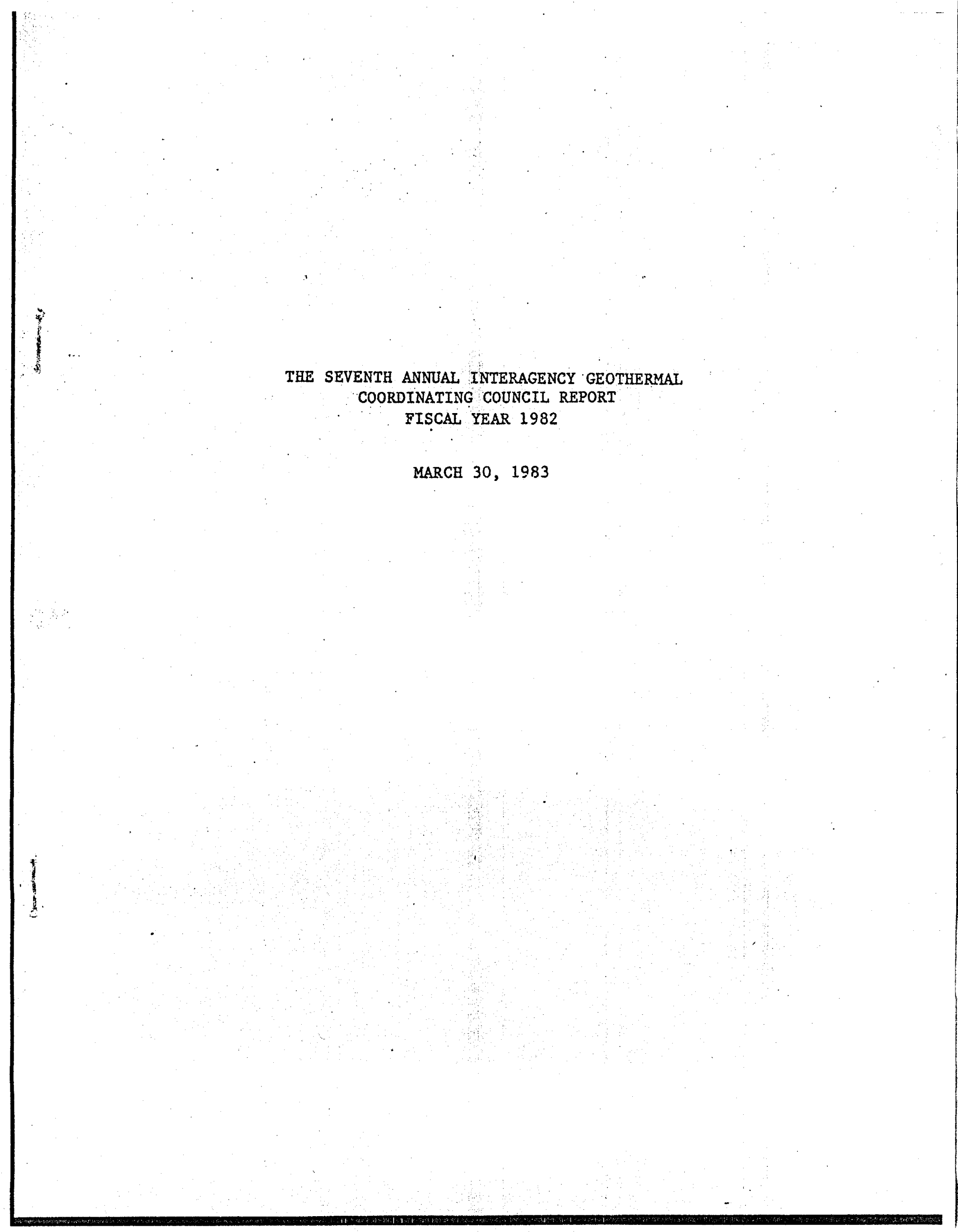


Geothermal energy is the natural heat of the earth, and can be tapped as a clean, safe, and econoutcal alternative source of energy. Three types of geothermal resources (hydrothermal, geopressured and hot dry rock) are expected to be commercially exploited by the year 2000. Of these, only hydrothermal resources, which are underground accumulations of hot water or steam, are technically and economically feasible for exploitation at this time. Figure 1 is a map of the United States Indicating known and potential hydrothermal resources. Some of these resources are belng tapped now, but much more of this energy resource is recoverable with current or near current technology. Therefore, those resources could make a significant contribution both to increasing domestic energy supplies, and to reducing the Untted States' dependence on Imported oll. Moreover, It can be used for varlous purposes: electrlc power production, residential and comercial space heating and cooling, industrial process heat, and agrlcultural process applicatlons.

Although not intended as a statement of goals or targets, energy projectlons were prepared in July 1982 in conjunction with the Natlonal. Energy Policy plan. With a midrange total U.S. energy consumption in 1990 and 2000 of 87 and 99 quads, respectively, geothermal electric production of 0.2 and 0.4 quads and direct-heat use, of 0.07 and 0.2 quads are projected. Although these contributions would be less than one percent of national energy. consumption, reglonal contributions are expected to exceed several percent in a number of areas throughout the western U.S., with a much larger percentage in certain areas of California, Nevada, Hawal1, Utah, and parts of the Cascade Range. Thus, geothermal energy represents one of several alternate energy sources which will play an increasingly important role in the U.S. energy future.

The Federal government has been actively involved in the development of geothermal energy since 1970, when the Geothermal steam Act was passed. Since then 1t has been engaged in the leasing of Federal lands as well as numerous research, development, and demonstration programs to investigate the use of geothermal energy. This report summarizes the accomplishments of the Federal government during flscal year 1982, and describes Federal geothermal energy programs. Table 1 presents a chronological history of significant geothermal energy developments.

In 1982, an overall objective of the Federal geothermal program was to respond to the needs of private industry by undertaking longterm, hlgh-risk, potentlally high-payoff R\&D, thus enabling private industry to undertake commercial development of geothermal resources; the Federal Government provided an approprlate level of assistance while removing technlcal barrlers to exploration and development. Private Industry's leading role in the direct planning and construction of geothermal energy systems other than DOE sponsored test br pilot plants, reflects the Administration's pollcy of relying on the marketplace for energy industrialization activities, including geothermal. 
SIGNIFICANT EVENTS IN THE DEVELOPMENT

OF GEOTHERMAL ENERGY IN THE UNITED STATES

1894 District heating implemented In Boise, Idaho

1900. Hot water provided to homes in Klamath Falls, Oregon

1916 Power generat1on at The Geysers resort

1927 First exploratory geothermal wells were drilled in Imperial Valley, Callfornia by Ploneer Development Company

1959 Small pilot plant operated near N1land, California on Sinclair No. 1 well

1960 Commerclal electriclty generated from dry steam at The Geysers, California

1970 Geothermal Steam Act Passed (PL 91-581)

1972 NSF became lead agency for Federal Geothermal Programs

1973 USGS, AEC, NSF prepared the first Federal Geothermal Program Plan

1974 Geothermal RD\&D Act passed (PL 93-410) which included the establishment of the Geothermal Loan Guaranty Program (GLGP)

1975 ERDA formed; Division of Geothermal Energy formed primarily from NSF, AEC staff

USGS released first national geothermal resource estimates and Inventory

1977 DOE formed; DGE continued to manage the program

Bureau of Reclamation successfully completed desalting tests to produce fresh water from geothermal brines

1978 Energy Tax Act passed (PL 95-618)

EPA 1ssued pollution control guldellnes for geothermal energy development

Successful Hot Dry Rock experiment conducted In New Mexico

F1rst geothermal crop-drying plant bullt in Nevada 
TABLE 1

SIGNIFICANT EVENTS IN THE DEVELOPMENT

OF GEOTHERMAL ENERGY IN THE UNITED STATES (ContInued)

1979 USGS released updated national geothermal resource estimates and inventory

Streamlining task force recommended measures to speed Federal leasing to IGCC

U.S. Navy awarded a contract to develop $75 \mathrm{MWe}$ at the Coso KGRA on the Naval Weapons Center, China Lake, California

First geothermal electricity produced from Federal lands, at The Geysers; Callfornia

World's first experimental binary cycle plant. (-1.0 MWe) built by Industry at East Mesa, Callfornia

Issued the first Geothermal Loan Guarantee to Geothermal Food Processors, Inc., for an onton drying plant at Brady Hot Springs, Nevada

1980 World's largest single geothermal power unlt (129 MWe) generated electricity at The Geysers, Callfornia

10 Me flash-steam plant bullt by Industry at Brawley, California

First electric power from a Hot Dry Rock resource produced at Fenton Eill, New Mexico

F1rst geothermal ethanol plant began production at La Grande, Oregon, under private funding

FIrst 5 DOE-sponsored fleld demonstrations of direct heat applications became operational

First deep geothermal reservolr confirmation well drilled in Atlantic Coastal Plain, near Crisfield, Maryland

Crude 011 Windfall Profits Tax Act passed, providing tax cred1t Increase for geotherwal equipment (PL 96-223)

Energy Security Act, containing Title VI, "The Geothermal Energy Act of $1979^{\circ}$, passed (PL 96-294)

1981 First U.S. geothermal electric generation plant outside the 48 contiguous states brought on-ine in the Puna resource areas in Hawail

The Insurance Company of North America began offering insurance against the financlal risk of reservoir fallure 
SIGNIFICANT EVENTS IN THE DEVELOPMENT

OF GEOTHERMAL ENERGY IN THE UNITED STATES (Continued)

The practical demonstration of generating electricity from moderate-temperature geothermal fluids was accomplished at Raft River, Idaho

A mobile we11-head generator with a net output of 1.6 MWe was Installed at Roosevelt Eot Springs, Utah

USGS research drilling at Newberry Volcano, Oregon, Indlcated for the first time that temperatures $\left(256^{\circ} \mathrm{C}\right.$ at $\left.3,057 \mathrm{ft}\right)$ sufficient for electrical production existed in the Cascade Range

A 76 MW geothermal electric powerplant was certified by the Federal Energy Regulatory Commission as a Qualifying Small Power Production plant using a renewable energy source. The plant is to be constructed in the Imperlal Valley, California by Republic Geothermal, Inc. Qualifying power production facilities are entitled to the benefits specified urder Section 210 of PURPA

1982 A 10 MWe flash plant ut1lizing hypersaline brine began operation at the Salton Sea, RGRA, California

On January 19, 1982, the Secretary of Interfor established the Minerals Management Service (MS) by Order No. 3071: MMS performs the functions previously carried out by the Conservation Division of the USGS. On December 3,1982, by Order No. 3087, the Secretary transferred the functions performed by the Onshore Minerals Management Service from MMS to the Bureau of Land Management

An $80 \mathrm{MW}$ geothermal electrlc powerplant to be constructed by Occidential Geothermal, Inc. in Lake County, Californla and a 49 MW geothermal electric powerplant to be constructed by Republic Geothermal, Inc. and the Parsons Corporation in the Imperial Valley, Callfornia were certified by the FERC as quallfying facilitles. Magma Power Company and Magma Development Corporation issued a public notice of self-qualification for an existing 11 MW geothermal powerplant located in East Mesa, Callfornia

In an effort by DOI to accelerate the geothermal leasing program, a record 16 competitive lease sales were held in which 578,656 acres were offered 
SIGNIFICANT EVENTS IN TEE DEVELOPMENT

OF GEOTHERMAL ENERGY IN. THE UNITED STATES (Concluded)

USGS completed the first quantitative national assessment of low-temperature $\left(<90^{\circ} \mathrm{C}\right)$ geothermal resources of the United States

An additional 140 MWe of power generating capacity from geothermal energy was brought on line in 1982, bringing current on-1ine capacity to 1167 MWe 
The efficient and timely development of geothermal resources depends on the coordinated efforts of Federal, state, and local governments; Industry, consumer and environmental groups; and private citizens. Federal responsibilities and programs are divided among a number of agencles whose activities are coordinated through the Interagency Geothermal Coordinating Council (IGCC), which was established In 1974 by PL 93-410. The IGCC brings together all of the Federal agencles with responsibilities related to geothermal energy development, and serves as a forum for interagency program coordination and information exchange.

The IGCC consists of the Federal agencles which participate in the geothermal program and is responsible for supervising and coordinating the activities of the Federal government community. This responsibility is spelled out in the Geothermal Research, Development, and Demonstration Act of 1974 (PL 93-410); specif1cally it is "...to coordinate those Federal plans, activities, and pollcles which are related to or impact on geothermal energy, lncluding auxillary activities of agencles not represented in the counc1l membership". The Counc1l, through the Chalrman, may make recommendations to the appropriate agencles and the President with regard to alternative pollcles or action considered necessary or desirable to expedite the development and utilization of geothermal energy resources. Member agencles Include the Departments of Energy, Commerce, Defense, Interior, BousIng and Urban Development, Treasury and Agriculture, and the Environmental Protection Agency. The Federal Geothermal Program budget of the nember agencies is presented in Table 2.

\subsection{LEASING}

The goal of Federal geothermal leasing activities is to make lands avallable to Industry for exploration and development. Leasing Is accomplished by the Bureau of Land Management, with the consent of the Forest Service where National Forest System Lands are Involved.

During FY 1982, the Federal government 1ssued leases for $1,044,390$ acres, more than twice the expectation of the Leasing Pollcy Development Office $(500,000$ acres per year). Federal leases are issued either through the competitive or non-competitive leasing program.

\section{Competitive Leasing}

The Bureau of Land Management (BLM) conducts competitive geothermal lease sales several times each year. At the lease sales, parcels of land located in Known Geothermal Resource Areas (KGRAs) are offered to the public. Typlcally, a lease sale Involves several tracts of land; each tract is bid on separately. The highest qualifled bidder receives rlghts to explore and develop the geothermal resources, conditioned on compliance with applicable laws, regulations, and lease terms of the sale, and geothermal operational orders. 
FEDERAL FUNDING FOR GEOTHERMAL ENERGY (\$000)*

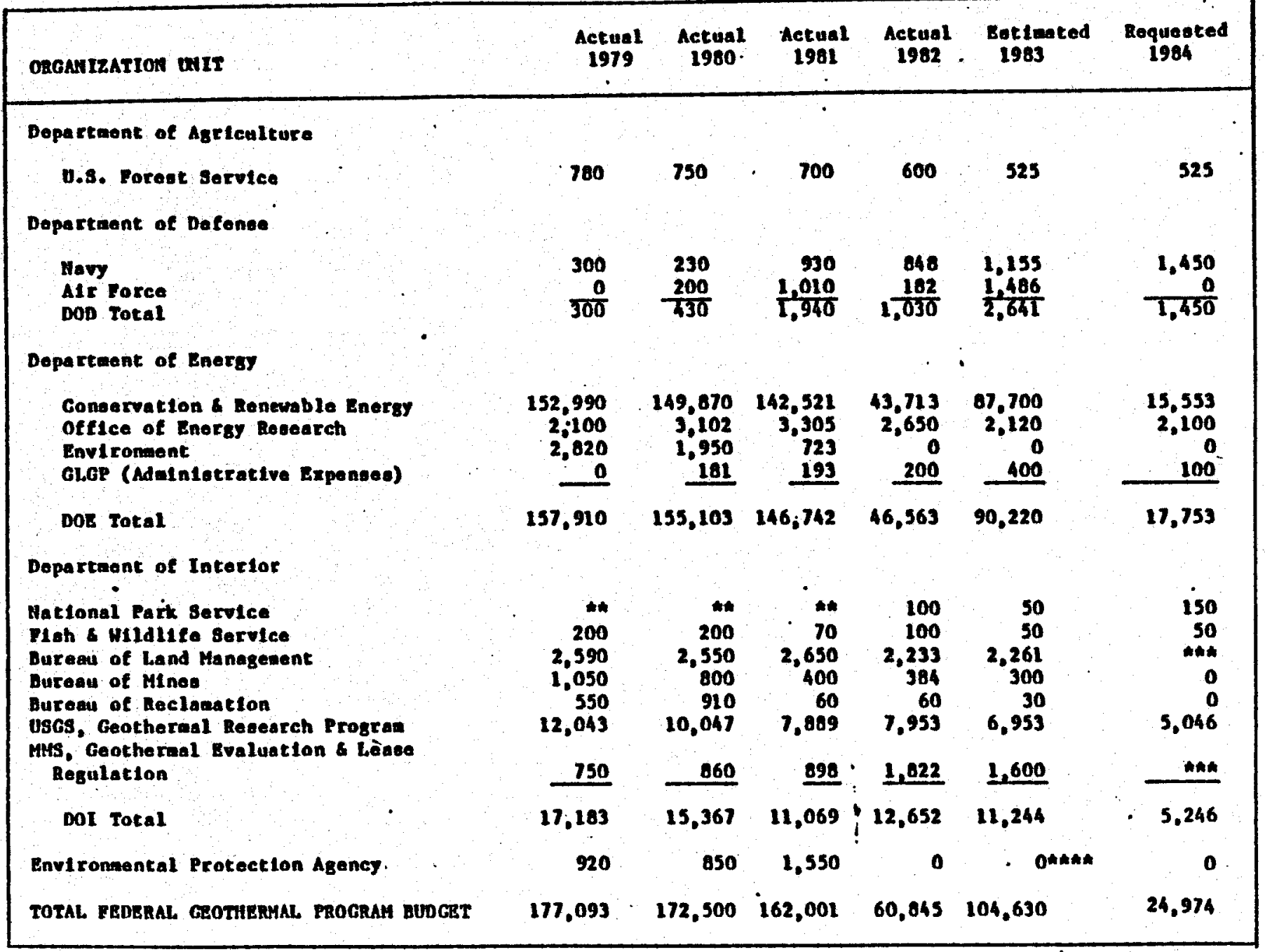

* Dudget authority counded to nearest thousand.

th Hot known.

the Not known due to MHs/DLM Coneolldation.

* thit While the FY 83 EPA budget doeg not target resources specifleally for geotherral, other RSD at EPA (e.8.. dieposal of liquid effluente) or prograsmatle activitles (e.g., permitting asatatance to atatea) may be applicable to goothermal energy. 
Durlng FY 1982, the Federal government recelved $\$ 23,550,522$ of acceptable bonus bids for 203,413 acres leased through the competitive process. Table 3 is a breakdown of acreage leased competitvely in FY 1982 on a state-by-state basis and includes acceptable bonus b1ds generated from these sales. Table 4 presents acceptable bonus bids from competitve lease sales In FY 1982 and the total for all years (1974-1982). Table 5 delineates the average high bid price per acre in FY 1982 at KGRA sites. With the exception of 1974 and 1978 when Federal land at The Geysers was offered, 1982 saw the highest average price per leased acre. Since 1980 , the average price per acre has increased from $\$ 32.52$ in 1980 to $\$ 84.41$ in 1981 to $\$ 108.86$ 1n 1982. A major factor in these increases has been a better understanding of the nature, occurrence, and utilization of geothermal resources as a result of RED studies. Table 6 is a summary of the competitive leasing process, and indicates acreage leased by state, by year.

Non-competitive Leasing

Non-competitive leases are issued by the Federal government on land not located within a KGRA. During FY 1982, 804,977 acres were leased through this process. Table 7 summarlzes the non-competitive leasing activity.

Post-lease Operat1ons

The Office of the Deputy. Minerals Manager for Geothermal (DMM, Geothermal) is responsible for the regulation of all phases of post-lease geothermal development on Federal leases. The level of geothermal activity on Federal leases during fiscal year 1982 remalned falrly constant when compared with the previous two fiscal years. The number of shallow temperature gradient wells drilled decreased from 106 and 124 for FY 1980 and FY 1981 respectively, to 89 for FY 1982. However, the number of deep wells drilled in FY 1982 Increased to 35 from FY 1980 and FY 1981 totals of 27 and 30 .

Of the twelve power plants in various stages of certification or construction at the end of FY 1982, four are located on Federal land and two on Federal leases on Stock-Ralsing Homestead Land. Construction of the Northern Californla Power Agency $\$ 2110$ MW power plant in The Geysers was approximately $90 \%$ complete, and construction of the Sacramento Municipal Utility District 72 MW plant was $50 \%$ complete. The remalning three plants in The Geysers are in the certification process or the early stages of constructlon. At koosevelt Hot Springs, Utah, the Utah Power and LIght Company and Phillips Petroleum Company began construction of a $20 \mathrm{MW}$ power plant at the end of FY 1982. Phillips drilled two new production wells during FY 1982 at Roosevelt Hot Springs, and testing showed these to be the best producIng wells in the unit. 
TABLE 3

TOTAL ACREAGE LEASED COMPETITIVELY IN FY 1982

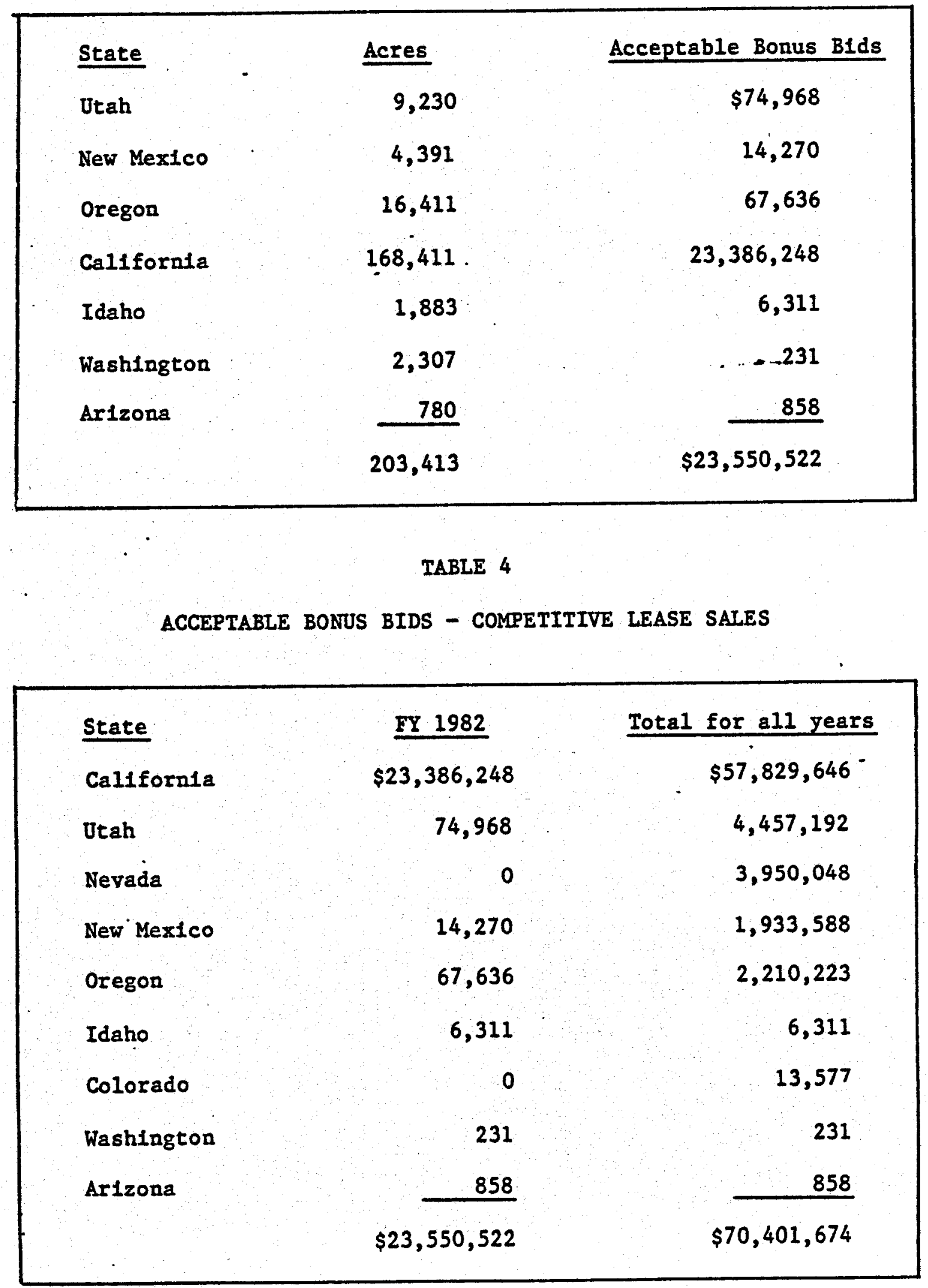


TABLE 5

AVERAGE HIGH BID PRICE PER ACRE

FY 1982

\begin{tabular}{|c|c|c|}
\hline State & KGRA. Site & $\frac{\text { Average Price }}{\text { Per Acre }}$ \\
\hline California & $\begin{array}{l}\text { East Brawley } \\
\text { The Geysers-Calistoga } \\
\text { Randsburg } \\
\text { Glass Mountain } \\
\text { Lake City - Surprise Valley } \\
\text { Coso Hot Springs } \\
\text { Wendel - Amedee } \\
\text { Knoxville } \\
\text { Bodie. } \\
\text { Mono-Long Valley } \\
\text { Salton Sea }\end{array}$ & $\begin{array}{r}\$ 150.66 \\
878.77 \\
114.16 \\
258.85 \\
3.00 \\
12.00 \\
20.25 \\
31.05 \\
2.00 \\
20.66 \\
9.56\end{array}$ \\
\hline New Mexico & Socorro Peak & 3.25 \\
\hline Arlzona & Clefton & 1.10 \\
\hline Oregon & $\begin{array}{l}\text { Alvord } \\
\text { Crump Geyser } \\
\text { Klamath Falls } \\
\text { Vale Bot Springs }\end{array}$ & $\begin{array}{l}9.37 \\
2.54 \\
2.08 \\
1.53\end{array}$ \\
\hline Idaho & Raft RIver & 3.35 \\
\hline Dtah & $\begin{array}{l}\text { Cove Fort - Sulphurdale } \\
\text { Roosevelt Eot Springs }\end{array}$ & $\begin{array}{l}8.63 \\
1.31\end{array}$ \\
\hline Washington & Indian Heaven & 0.10 \\
\hline & GRAND TOTAL AVERAGE: & $\$ 108.86 *$ \\
\hline
\end{tabular}

* The acreage leased at each site is accounted for in this welghted average. 
TABLE 6

COMPETITIVE LEASING BY STATE, TOTAL ACREAGE LEASED, BY YEAR

\begin{tabular}{|c|c|c|c|c|c|c|c|c|}
\hline STATE & $1974-1976$ & 1977 & 1978 & 1979 & 1980 & 1981 & $1982 *$ & Total for all Years \\
\hline Mevada & 120,996 & 36,663 & 9,322 & 24,298 & 20,419 & 15,304 & 0 & 227,002 \\
\hline Utah & 76,539 & 12,788 & 1,658 . & o & o & 0 & 9,230 & 100,215 \\
\hline New Mexico & 32.564 & 48,065 & $B, 767$ & 7,063 & $\mathbf{0}$ & 13,835 & 4,391 & 114,685 \\
\hline Oregon & 68,872 & 0 & 5,818 & o & 32,630 & 0 & 16,411 & 123,732 \\
\hline Caltfornia & 36,937 & 2,856 & 4,395 & 6,959 & 10 & 84,914 & 168,411 & 306,782 \\
\hline Idaho & 24,903 & 6,985 & 0 & o & o & 0 & 1,833 & 33,711 \\
\hline Colorado & 5,036 & 0 & o & 0 & o & $\mathbf{0}$ & $\mathbf{0}$ & 5,036 \\
\hline Hashington & o & o & 0 & $\mathbf{0}$ & 0 & o & 2,307 & 2,307 \\
\hline Artzona & 0 & 0 & $\mathbf{0}$ & 0 & 0 & 0 & 780 & 780 \\
\hline $\begin{array}{l}\text { Total Acres } \\
\text { leased }\end{array}$ & 365,847 & 107,357 & 29,960 & 38,320 & 53,059 & 114,053 & 203,413 & 914,310 \\
\hline
\end{tabular}

* Totals Include pending leases which way take up to 1 year after sale to be awarded. 
TABLE 7

CUMULATIVE NONCOMPETITIVE LEASE TOTALS, 1976 - 1982

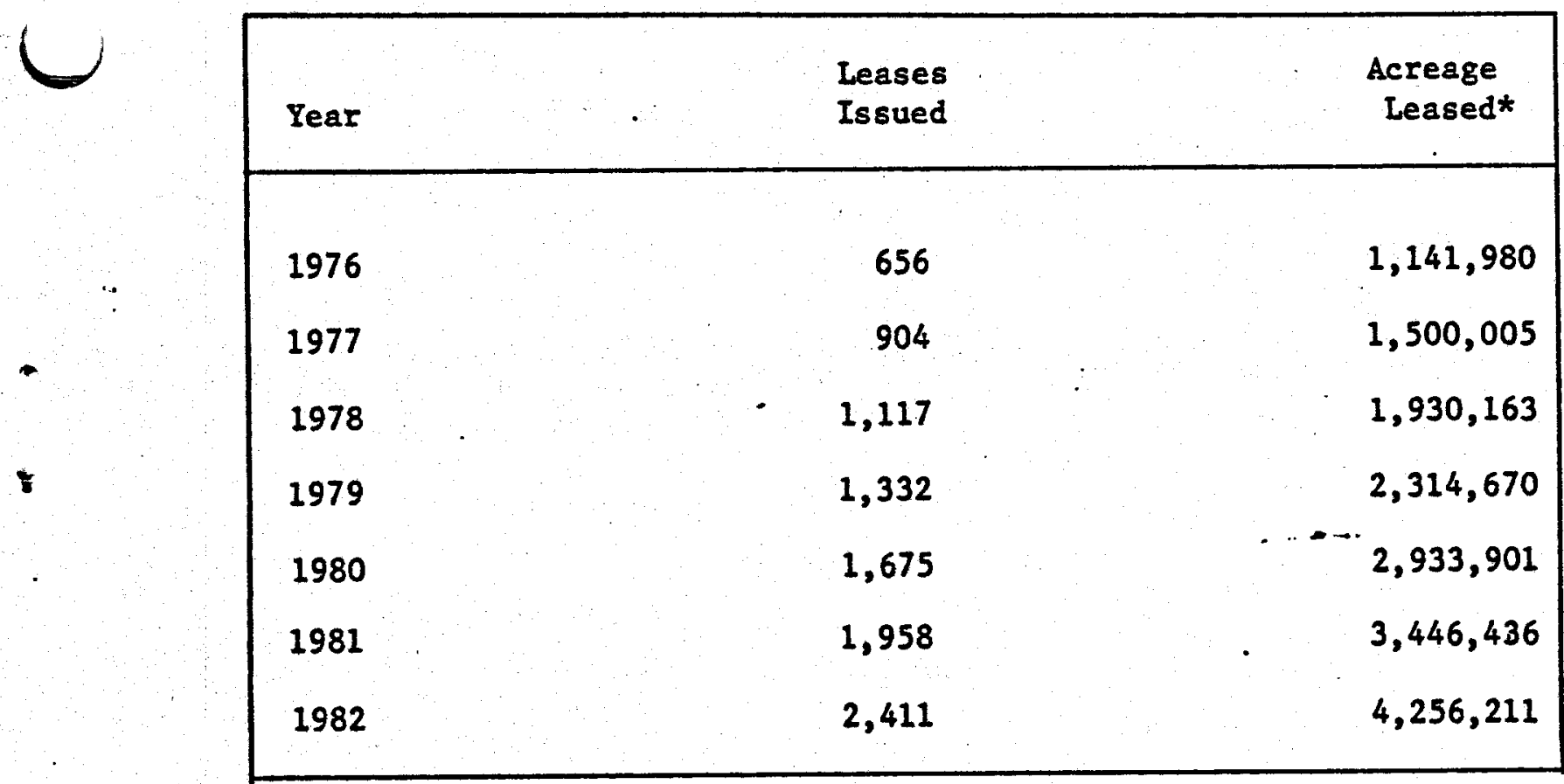

* Includes acreage subsequently rellnquished. 
of the six power plants under certification or construction on private lands, three will utilize wells located elther on Federal land or within a Federal unit. In addition, plans for Environmental Baseline Data Collection, a preliminary step for approval of a power plant, were submitted for three Federal areas in Nevada. Royalties collected in FY 1982 from geothermal production on Federal land totalled approximately $\$ 2,000,000$ in Californla and $\$ 5,000$ in New Mexico.

\subsection{HYDROTHERMAL RESOURCE IDENTIFICATION, ASSESSMENT, AND EXPLORATION}

The Unlted States Department of Energy and the United States Geological Survey have several programs designed to evaluate the geothermal energy potential in the U.S. These programs are complementary in nature but focus on different aspects of this goal. USGS activities emphasize geothermal resource inventory and assessment work; DOE activities focus on more detalled study of specific resource areas. The main objectives of the programs are to: (1) charactize the geological, hydrological, geochemical, and geophysical nature of the varlous types of geothermal resources; (2) estimate the location, distribution, and energy content of both the presently ldentifled and the undiscovered geothermal resources of the U.S.; (3) develop resource assessment technology; (4) conduct reglonal resource assessments and national resource inventories, and (5) contribute to the confirmation of selected specific geothermal reservolrs. The programs also address geoenvironmental effects and lssues dealing with longevity of geothermal systems.

Major accomplishments in FY 1982 Included:

- Completed the first quantitative national assessment of lowtemperature (less than $90^{\circ} \mathrm{C}$ ) geothermal resources of the United States. This provides an expanded basis for estimating the potential for non-electrical uses of geothermal energy throughout the United States.

- Completed the remaining maps of a six-map series that shows the distribution, rock type, and age of young volcante centers in the United States. These maps provide Information needed to assess geothermal potential related to the large number of magmat1c heat sources in the western 0.5 .

- Inftiated field studies and office compllation of a new geologic map of the Cascade Range. This map w11 provide key Information for the regtonal assessment of the large geothermal potential that is inferred but presently undiscovered in the Cascade Range from Washington into northern California. 
- Completed a selsmic refraction survey in the Mt. Shasta-Medicine Lake Highlands region of the Cascade Range in northern Callfornia; aeromagnetlc and gravity surveys of the Oregon and California parts of the Cascade Range; and a new geologic map of Newberry Volcano in central Oregon. Subsequent interpretation of these data will provide a framework for assessing the geothermal potential of the Cascade Range and for characterlz1ng the nature of this apparently large but relatively unknown resource.

- Published the results of a geologic study of the East Rift Zone of Kilauea Volcano in Hawa11. Potential magmatic heat sources were 1dentified in this important developing geothermal area.

- Completed aeromagnetic data collection for the San Francisco Volcanic Field in Arlzona. This completes all planned geophysical surveys for the geothermal assessment of this region.

\subsection{HYDROTHERMAL TECENOLOGY DEVELOPMENT}

The process of locating, produclng, and utllizing large volumes of fluids from high temperature, fractured, hard rock formations imposes number of technological and economic constralnts on geothermal development which forestail full-scale resource exploitation by the private sector. Conventional oll and gas technology, presentif employed for exploration, drilling, reservolr assessment, and production of geothermal flelds has proven expensive, unrellable and frequently non-functional in the hot, chemically hostile, dowahole geothermal environment. Surface equipment, including power plant components, lack the efflclency and reliablifty for electric power generation for all except the high temperature, high flow rate, most benign hydrothermal reservolrs. As a result, only a small percent of the avallable hydrothermal reservolrs can be economically exploited with current technology.

The current R\&D activitles are in areas of high-risk and are directed toward substantially reducing hard rock drilling costs, increasing moderate temperature energy conversion efficiency through blnary cycle technology, increasing reservolr production rates through well stimulation techniques and improved downhole brine pump, developing rellable exploration techniques, greatly improving reservolr engineering methods for assessing site-specific capacity and longevity, and developing environmental control technology required to meet state and Federal standards for geothermal alr emissions, and solid and liquid waste disposal.

Major accomplishments in FY 1982 included: 
- Designed and developed a new concept for drilling using a cavitating fet nozzle to enhance the drilling rate of existing bits.

- Successfully tested an inertial navigation system, adopted for use as a high-accuracy well surveylng tool.

- Successfully tested the use of a non-corrosive Inert gas (nitrogen) drilling technique; completed the design of an Inert gas generator (diesel exhaust purifler).

- Completed assembly of a facility for test of materials and techniques to control lost circulation.

\section{Energy Conversion Technology}

- Field tested a $500 \mathrm{kWe}$ direct contact heat exchanger in a binary cycle pilot plant at East Mesa, CA.

- Completed fleld test of 1 MWe hellcal screw expander (total flow power system) in Italy under IEA agreenent.

- Completed testing of 1sobutane/hexane working fluld mixtures In the $60 \mathrm{kWe}$ prototype power system at Raft River site.

- Achleved continuous operation of a geothermally hardened 80 IIP electric downhole brine pump for a record-setting 11 months.

\section{Reservolr Stimulation Technology}

- Completed two acid-wash well treatments at the Baca, N.M. site, resulting in increased well production but with flow rates short of single-well requirements for a comerclal-size power plant.

\section{Geochemical Engineering and Materials Research}

- Successfully completed testing of a carbonate scale Inhibitor

- Installed isobutane corrosion probes and Initlated testing under operating conditions at the 10 Mhe power plant at East Mesa, CA.

- Completed evaluation of designs of $\mathrm{CO}_{2}$ and $\mathrm{pH}$ probes for monitoring hydrothermal power plant operations.

- Completed high temperature brine tests of perfluorocarbon elastomer seals. 
Geoscience Technology

- Completed field testing of the EM-60 (electromagnetic exploration system).

- Completed fleld testing of the Automated Selsmic Processor which is a real-time, field-portable microearthquake location and analysis system which is currently being marketed by private 1ndustry.

- Completed the collection and evaluation of reservoir performance data from the Cerro Prieto geothermal field.

\section{Eydrothermal Power P lant-Projects}

- Completed $95 \%$ of the final design and Initlated long-leadtime equfment procurements for lieber 50 MWe geothermal binary cycle power plent.

- Completed operational tests of the 5 MWe Raft River binary cycle, pilot plant.

- Completed phase-out activities and most of the site restoration work on the 50 MWe flash-steam power plant project at Baca, N.M.

\subsection{HOT DRY ROCK RESOURCES}

The goal of the Hot Dry Rock (HDR) Program is to establish the technical feasibility of extracting energy from the earth's hot, water-deficient rocks. Intermediate objectives to attain the realization of this goal include: (1) developing a technology base for EDR energy extraction; (2) confirming that the resource potential is large and accessible; and (3) verlfying that resource development can be undertaken with acceptable environental effects. Successful demonstration of the technical feasibility of extracting $B D R$ energy has been proven with a 5 megawatt (MW) thermal loop at Fenton Bill, New Mextco.

Major accomplishments in FY 1982 included:

- Experimental data from the 5 MW thermal loop at Fenton Hill have been analyzed and published results indicate that recoverable heat from the reservoir is 6 times larger than originally estimated due in part to the thermal contraction effects as well as pressurization and hydraulic fracturing.

- A preliminary assessment of UDR resource potential was completed and 24 prospective sites were 1dentified.

- A revised thermal gradient map for the continental U.S. was completed. 
- Results of evaluations of BDR exploration techniques were completed and published.

- Five sep̀rate hydraulic fracturing experiments we re conducted 1n the injection well of the new HDR system at Fenton Hill.

- The 5 million gallon water storage pond at Fenton Eill was completed, lined, and covered. The pond will supply make-up water to the new HDR thermal. loop presently under construction.

\subsection{GEOPRESSURED RESOURCES}

During the past several years, the Geothermal Geopressured Program has established that there is a very large quantity of hot brine contained at high pressure in sandstone aquifers beneath the Texas-Loulsiana Gulf Coast. Essentially all of this brine is saturated with dissolved natural gas (methane), for a total of about 5,700 quadrillion (quads) BTU's of gas in place (D.S. gas consumption is about 18 quads/year). The thermal energy content of the brines is about equal to the chemlcal (methane) energy content, although the recoverable themal energy is less than that of the gas. It is technically feasible to produce the brine at high rates through wells, separate the gas, and inject the spent brine Into sultable underground formations. The princlpal program activity is the production testing of four specially-designed wells. Brine flow. rates of up to 40,000 barrels per day will provide data on geopressured reservoir performance. Analys is of these data should allow Industry to predict how much methane and thermal energy can be recovered from a geopressured reservolr.

Major accomplishments in FY 1982 included:

- Completed a well at the Parcperdue site in Loutsiana and acquired 6 months of production test data.

- Repalred a well In Brazoria County, Texas, and resumed flow tests.

- Determined the cause of tubing fallures 1n the McCall well in Loulsiana, and infliated a repair effort.

\section{7. $0^{\circ}$ GEOSCIENCES RESEARCH}

Numerous entitles, lncluding the Office of Energy Research of the Department of Energy and the Unlted States Geological Survey, Bureau of Mines, and the Bureau of Reclamation within the Department of Interior, have undertaken R\&D activities in the geosciences area. A significant portion of these activities is centered on the conduct of basic R\&D. Research and development activities have been struc- 
tured to resolve uncertainties in determining the location, size, chemical and temperature characteristics, and longevity of geothermal reservolrs. In addition to research and development activitles that have been conducted in the area of resource recognition and evaluat1on, other geothermal-related activitles, such as mineral recovery from geobrines and the production of fresh water supplies through the desalting of geothermal brines, have been undertaken.

Major accomplishments in FY 1982 included:

- Continued research to devise and demonstrate technology for the recovery of mineral and metal values from geobrines. Two papers were presented durIng FY 1982: "Corrosion of Carbon. and Alloy Steels in Salton Sea Geothermal Environment," and "Corrosion of N1ckel Alloys in Salton Sea Geothermal Environment." The geobrine work is scheduled for completion in FY 1983.

- Researchers at MIT have developed methods to determine the extent, orlentation, multiplicity, and spacing of fractures In regions of geothermal potential from data obtalned in downhole active selsmic experiments.

- Experiments at Sandia National Laboratory have demonstrated that high levels of energy extraction from magma are possible.

- Experiments recently reported by Sandia National Laboratory have provided the first results that show superconvection near the critical point in a fluld saturated permeable medium. Heat transfer rates increased by a factor of 70 or more as the critical point was approached. Enhanced heat transfer of this type has potential application to geothermal energy extraction.

- Completed preliminary resource investigations in California, Arizona, New Mexico, and Nevada. The-investigations have been undertaken with the objective of producing fresh water supplies through the desalting of geothermal brines.

- Completed computer modeling of a hydrothermal convection system to predict hydrologic behavior under varlous assumed conditions of fluld flow and withdrawal.

\subsection{HYDROTHERMAL TECENOLOGY TRANSFER}

The goal of the Eydrothermal Technology Transfer effort is to provide an appropriate level of Federal support to industry so that development of geothermal resources can proceed. The effort focuses on low-to moderatetemperature resources for direct applications and high-temperature geothermal resources for electric power generation. Eydrothermal resource development is impeded by the private sector's 
perception of economic and technical risk, reservolr performance uncertainties, and a variety of legal and institutional barriers.

DOE's Hydrothermal Technology Transfer effort in FY 1982 consisted of information dissemination; legal and regulatory reform and streamilning; site-specific direct heat feasibility studies and fleld demonstrations; and administration of the Geothermal Resources Development Fund. The Geothermal Energy Research Development and Demonstration Act of 1974 provided for the establishment of the Geothermal Loan Guaranty Program (GLGP) and of the Geothemal Resource Development Fund (Table 8 presents the FY 1982 status of the Fund) to support the program. The objectives of the GLGP are to encourage the private and public sectors to accelerate the utilization of geothermal resources by minimizing lenders' flnancial risk; develop a financlal service lnfrastructure to ultimately provide financing of geothemal projects without Federal assistance; promote competition and encourage new entrance of firms into the geothermal marketplace.

Financlal and economic incentives for private sector development. are also provided by other Federal agencles. The Departments of Commerce and Eousing and Urban Development offer financing opportun1ties for geothermal development in thelr grant programs. Communities may choose to utilize thelr HUD Community Development Block Grant (CDBG) funds for this purpose, and may request Urban Development Action Grants (UDAG's) provided that private sector leveraging and other requirements are met. Dur1ng FY 1982, HuD funded 4 preliminary feasibility studies of geothermal district heating systems: Bellows Falls, Vermont; Berlin, Maryland; Thermopol1s, Wyoming; and Union County, Oregon. Total funding for the four projects was approximately $\$ 200,000$.

\subsection{ENVIRONMENT}

The Federal Geothermal Environment Program focuses on character1zation of the environmental impacts from the development of geothermal energy sources and the development and evaluation of control methods to mftigate or eliminate environmental concerns, including health. The coordination between the private sector, the research community, and Federal and state government agencles on environmental matters is provided by the IGCC's Enviromental Controls Panel. The Environmental Controls Ranel successfully completed its effort in FY 1981 to refocus and integrate Federal environmental research programs, with ERA, DOE and DOI belng the principal participants in the environmental program. The environmental program has included acquisitfon of baseline data, monitoring, and research related to alr qual1ty, surface and ground water quality, hydrological alterations, ecology, solid residuals, subsidence and selsmiclty, health effects, and socioeconomic problems; reglonal and site specific assessments of the environmental, health; and socloeconomic impacts of geothermal resource development; and development and evaluation of environmental control technologies. 
GEOTHERMAI RESOURCES DEVELOPMENT FUND(1)

AND GUARANTY AUTHORITY

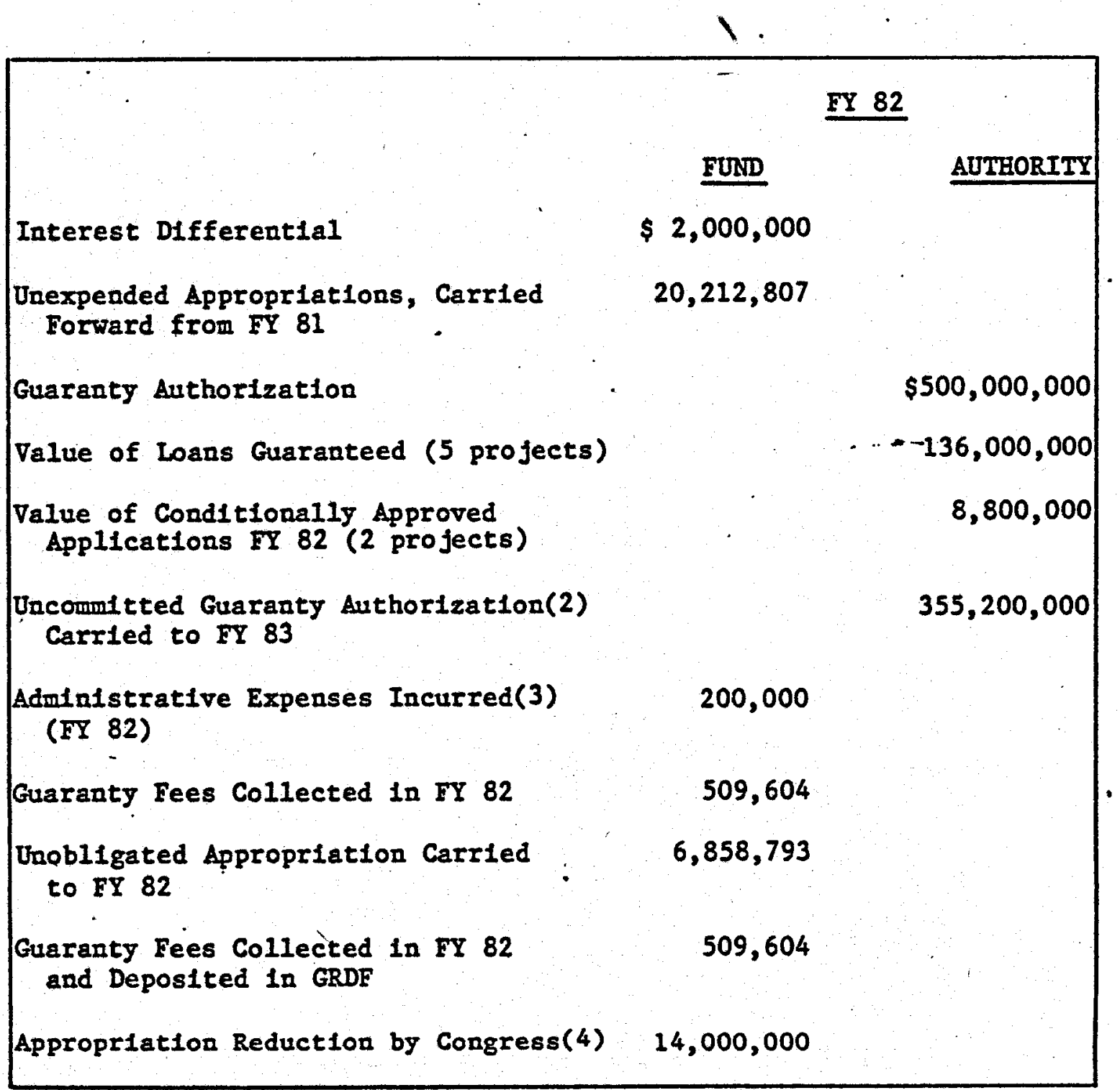

(1) This financial Information is included in the Seventh Annual Report to satisfy the requirements of PL 93-410, Section 204.

(2) The value of applications currently under review is $\$ 300,600,000$. In addition, of the $5 \cdot$ projects that currently have loan guarantees, certain of these may require follow-on loans for powerplant construction.

(3) Contractor and consultant costs necessary to assist in evaluating technological, geophysical, financial, marketing, management and legal data submitted with guarantee applications and to assist in monitoring guaranteed projects.

(4) Appropriation transfer to another program. 
Major accomplishments in FY 1982 Included:

- Completed a study for the IGCC of the difficulties of protecting hydrothermal features in national parks from adjacent geothermal development and recommendend general, technicallybased concepts to gulde Federal development and protection programs.

- Completed analyses of hazardous components of geothermal solid wastes at several U.S. sites. The degree to which solld wastes are hazardous appears to be directly related to the chemical nature of geothermal fluids: thus, only highsalinity flulds among those studied produced solld wastes which met some EPA criteria for hazardous wastes.

- Completed a survey of environmental regulations and updated Federal, state, and local regulations applicable to geothermal energy development. This revised guidebook can be used by industry and state/local regulators as $\vec{a}$ planning tool.

- Completed a study of electrochemical removal of dissolved sulfate from geothermal brines. This bench-scale study found that hydrogen-sulfide $\left(H_{2} S\right)$ can be removed successfully from geothermal brines upstream of the energy conversion system wl th only a small ( $<1 \%$ ) energy penalty.

- Completed a "desktop" assessment of non- $\mathrm{H}_{2} \mathrm{~S}$ emissions. Ava11able data from sources world-wide were evaluated to understand the extent of non- $\mathrm{H}_{2} \mathrm{~S}$ alr pollution emission problems. The study found that treatment for non- ${ }_{2} S$ emissions is not likely to be needed at most geothermal sites.

- Completed an enviromental assessment of sub-surface injection of spent geothermal flulds. Based on an examination of avallable hydrological and geological data from several geothermal resources in the western U.S., few environmental problems are foreseen with injection requirements that appear likely to be applied. Significant contamination of drinking water-quality aquifers does not appear likely if available practices for careful, cost-effective injection are followed.

- Completed an environmental assessment of direct uses of geothermal energy. Avallable data revealed no occurences of enviromental degradation at over 100 sites world-wide where direct use of geothermal energy exists and where basic precautions we re followed to protect environmental quality. No sites where damage occurred were identifled. 
- Completed chenical analyses of geothermal fluids from Lassen Volcanic National Park in northern Callfornia and adjacent areas. Preliminary interpretation of the analyses indicates that a single, high-temperature, vapor-dominated geothermal system is centered beneath the Park and that a deeper hot-water part of this system feeds hot springs in the Lassen RGRA outside the Park.

\subsection{FEDERAL USE OF GEOTEERMAL ENERGY}

Where economically appropriate, the Federal goverment has been Involved in the utilization of geothermal resources. In particular, the Department of Defense: has been active in the development and use of geothermal energy at several milltary installatlons throughout the U.S. and the world.

Major accomplishments in FY 1982 included:

- An Invitation for bids (IFB) for developing up to 75 MWe from the geothermal resource at the Naval Air Weapons Training Complex, Fallon, Nevada was 18sued in August 1982. Two bids were recelved at bid opening in October 1982. The Navy expects to award the contract in the Immediate future.

- The Navy awarded a contract to develop up to 75 MWe at the Coso RGRA on the Naval Weapons Center, China Lake, California in December 1979. By 1982, the contractor had completed the formal environmental hearing process and drill hole siting. The contractor drilled six geothermal wells in 1982, which are all considered to be economically vlable producers with their power output totaling approximately $40 \mathrm{MWe}$.

- Conversion of bulldings to a geothermal heating system at the U.S. Naval Station at Keflavik, Iceland was about two thirds complete in FY 1982. The project will provide a geothermal flufd distribution system and convert over 300 buildings to use the geothermal energy. The bulldings already converted displaced approximately 18,140 barrels of oil in 1982 . When the project is complete approximately 167,000 barrels of o11 will be displaced per year.

- The Alr Force did a feasibillty study in FY 1982 for using a hot water geothermal resource at Lackland AFB, Texas. The study showed the best application is to heat 6 dormitory type bulldings, which would have about a 7-year payback. The Air Force 1s working with DOE/Idaho Falls to do a more advanced geologic study and to drill a test well in FY 1983. 
- The Alr Force did a preliminary feasibility study, which was completed in September 1982, to use a geothermal resource at the alr base on Ascension Island, in the South Atlantic Ocean. The study showed potential to generate electricity from the resource. The Air Force intends to conduct more advanced geologic testing and to drill test well in 1983.

- The Navy completed a geothermal evaluation for the Marine Corps Air Station on the Island of Oahu, Hawa11. The report was published in June 1982. The study concluded that the probability of the existence of a useable geothermal resource is very small.

- The Navy is continuing to evaluate the geothermal potential of other sites such as Marine Corps Base, Twentynine Palms, California and at the weapons test areas in the Imperial Valley through geologic/geophysical investigaţlons. and the drilling of thermal gradient holes.

- DOE continued its efforts to assist other Federal agencies in identifying bulldings and facilities that could use geother mal energy for heating and cooling.

\subsection{PRIVATE SECTOR USE OF GEOTHERMAL ENERGY}

Geothermal energy has been used for space heating in the United States since the early 1900's and for district heating systems since the 1930's. Current uses Include agricultural and aquacultural applications, spacel district heating, and Industrlal applications. Currently, direct utilization of geothermal energy is approximately .012 quads/yr. Most of the direct-utilization of geothermal energy is concentrated In Callfornia, Idaho, Nevada, New Mexico, Oregon, and South Dakota. Direct-utilization is expected to grow dramaticaliy over the next few years with signiflcant expansion projected in Industrial applications and district heating systems.

The production of electricity from geothermal energy first occurred in the United States in 1960 at The Geysers in California. Since that time numerous faclilties have been constructed and currently account for 1,167 MWe power-or-line. Over the next two years, several additional geothermal electric power facilitles are scheduled to begin operation in California_(Geysers-595 MWe, Imperial Valley-97 MWe), and Utah (Roosevelt Hot Springs - $20 \mathrm{MWe}$ ). 